\title{
HOUSING CONSUMPTION IN LATE LIFE: THE ROLE OF INCOME, HEALTH SHOCKS, AND MARITAL SHOCKS
}

Douglas A. Wolf and Janet M. Wilmoth

CRR WP 2010-10

Date Submitted: July 2010

Date Released: September 2010

\author{
Center for Retirement Research at Boston College \\ Hovey House \\ 140 Commonwealth Avenue \\ Chestnut Hill, MA 02467 \\ Tel: 617-552-1762 Fax: 617-552-0191 \\ http://crr.bc.edu/
}

Douglas Wolf is the Gerald B. Cramer Professor of Aging Studies at Syracuse University (SU). Janet M. Wilmoth is a senior research associate at SU. The research reported herein was pursuant to a grant from the U.S. Social Security Administration (SSA) funded as part of the Retirement Research Consortium (RRC). The findings and conclusions expressed are solely those of the authors and do not represent the views of SSA, any agency of the Federal Government, the RRC, SU, or Boston College. We thank Gary Engelhardt for providing the data for the instrumental variable, Jan Ondrich for providing useful advice, and Carrie Rosamelia for her assistance with this research.

(C) 2010, by Douglas A. Wolf and Janet M. Wilmoth. All rights reserved. Short sections of text, not to exceed two paragraphs, may be quoted without explicit permission provided that full credit, including (C) notice, is given to the source. 


\section{About the Center for Retirement Research}

The Center for Retirement Research at Boston College, part of a consortium that includes parallel centers at the University of Michigan and the National Bureau of Economic Research, was established in 1998 through a grant from the Social Security Administration. The Center's mission is to produce first-class research and forge a strong link between the academic community and decision makers in the public and private sectors around an issue of critical importance to the nation's future. To achieve this mission, the Center sponsors a wide variety of research projects, transmits new findings to a broad audience, trains new scholars, and broadens access to valuable data sources.

\section{Center for Retirement Research at Boston College Hovey House \\ 140 Commonwealth Avenue \\ Chestnut Hill, MA 02467 \\ phone: 617-552-1762 fax: 617-552-0191 \\ e-mail: crr@bc.edu \\ http://crr.bc.edu/}

Affiliated Institutions:

The Brookings Institution

Massachusetts Institute of Technology

Syracuse University

Urban Institute 


\begin{abstract}
Past research has shown that income from the Social Security program has contributed to trends towards smaller households, greater residential independence - the tendency to live alone rather than with others - and a greater prevalence of home ownership late in life. However, the mechanism through which these associations operate has remained relatively unstudied. This paper addresses the possibility that Social Security income mediates the consequences of adverse events, whether "health shocks" such as a stroke or hip fracture, or "marital shocks," principally the death of a spouse. We measure housing consumption using the ratio of dwelling unit size (number of rooms) to number of household members-i.e., "rooms per person.” We use panel data from the Health and Retirement Survey to model current housing consumption in relation to Social Security income as well as the occurrence of health and marital shocks over the two-year period preceding each survey year (1995; 2000; 2002; 2004; and 2006). We also use an instrumental-variables approach to deal with omitted-variables bias in the housing consumption equation, and include an additional control for selective loss from the sample due to entry into a nursing home. We find no effects of Social Security income on housing consumption once we control for selection and endogeneity, a result that contrasts sharply with past research findings. We also fail to find any evidence that Social Security mediates either health or marital shocks. However, we do find that health shocks, and to a lesser extent marital shocks, are strongly associated with both nursing home entry and changes in housing consumption.
\end{abstract}




\section{Introduction}

Social Security is widely viewed as one of the most successful social programs in U.S. history. The maturation of the program, accompanied by rising population coverage and a series of benefit adjustments, led to Social Security’s position as the main source of retirement income. As Social Security income grew, and poverty in the older population fell, household size decreased while the percentage of people living alone increased. Thus rising Social Security income has contributed to the increase in solitary living (Fuchs, Michel \& Scott 1980; McGarry \& Schoeni 2000) and has led to increased home ownership at older ages (Engelhardt 2008). Other income transfer programs, such as Supplemental Security Income (Tissue \& McCoy 1981) and its predecessor, Old Age Assistance (Costa 1990), have also been shown to promote independent household living. A recent study that used instrumental-variables techniques found an income elasticity of independent living among older adults-i.e., of living alone, if single, or as a couple if married — considerably larger than previously estimated (Engelhardt, Gruber \& Perry 2005).

Paradoxically, the very income increases that produced greater residential autonomy have also undermined improvements in old age poverty rates. Holden (1988) showed that the reduction in poverty among older women from 1950 to 1980—about 36 percent—would have been even larger were it not for the increased propensity of older women to live alone over that same time period. Thus older women used some of their increased income to achieve residential independence, at the cost of some foregone economies of scale in household composition (see also Engelhardt and Gruber 2004).

Although the connection between rising income levels in general, or rising Social Security benefit levels in particular, and independent living seem well established, little attention has been paid to the mechanism through which this connection is established. For example, Social Security's role in promoting home ownership late in life is unlikely to operate through the 
initial purchase of a home, which typically happens well before retirement. Rather, higherincome people may be able to remain in an owned home longer, or may be buffered from the adverse effects of health or marital shocks.

Other factors besides income also play a role in household composition at older ages. For example, it is well established that health and family composition (particularly adult children's characteristics) influence later life living arrangements. Older people with more surviving children are less likely to live alone (Macunovich et al. 1995; Palloni 2001). Moreover, declining health and increasing disability decrease the likelihood an older adult will live alone and increase the chances of living with others or being institutionalized (Angel 1991; Avery, Speare, and Lawton 1989; Mutchler and Burr 1991). It should be noted that when parent-child coresidence is prompted by an increase in the parent's needs for care and assistance, the coresidence could result from either the parent's move into the child's household, or the child's relocation into the parent's household. Little is known about the relative frequency of these two types of moves.

Income, health, and family characteristics also play a role in later life residential mobility. As described by Litwak and Longino (1987), there are three kinds of moves over the later part of the life course. The first occurs around retirement among those who are relatively healthy and wealthy. It often involves long-distance moves to amenity-rich, low-tax locations that support engaged retirement lifestyles (Duncombe, Robbins, \& Wolf, 2003; Haas \& Serow, 1993; Longino, Bradley, Stoller, \& Haas, 2008). The second move occurs when older adults begin to encounter moderate chronic disability. This assistance-seeking move, which is often undertaken by widows, tends to bring older adults in closer proximity to adult children and other family members (Bradsher, Longino, Jackson, \& Zimmerman, 1992; Longino, Jackson, Zimmerman, \& 
Bradsher, 1991; Miller, Longino, Anderson, James, \& Woley, 1999; Stoller \& Longino, 2001).

The third move, into nursing homes, is prompted by a decline in the older adult's health that overwhelms the ability of family and others to provide sufficient care (Angel, De Jong, Cornwell, \& Wilmoth, 1995; Gaugler, Kane, Kane, Clay, \& Newcomer, 2003; McAuley \& Usita, 1998; Wolinsky, Callahan, Fitzgerald, \& Johnson, 1993).

Each of these late-life moves may involve selling a home, which in turn presents an opportunity for “downsizing,” reducing one’s housing equity, or otherwise changing one’s consumption of housing. However, past research has shown that residential moves among the older population, which are relatively infrequent and often precipitated by events such as the death of a spouse, are just as likely to lead to increases in as to decreases in housing equity (Venti \& Wise 1989; 1990).

This study seeks to uncover the mechanism through which income influences housing consumption in late life. Specifically, we investigate the effects of income, and of health and marital shocks, on housing consumption. To deal with the potential endogeneity of income in our housing-consumption equations, we use an instrument for Social Security benefits that was developed by Engelhardt and Gruber (2004), and has been applied in several studies.

Our measure of housing consumption (or "crowding")—rooms per person, in the dwelling unit occupied—captures housing adjustments that arise as a consequence of downsizing, or a move into a family member's home, or a move by one or more family members into one's home. Downsizing, whether or not accompanied by a move into someone else's home, necessitates a residential move, whereas one's own home can acquire additional occupants in the absence of a move. The idea that income buffers the adverse effects of health and marital shocks suggests an interactive effect between income and the occurrence of such shocks. 
Accordingly, we estimate both main-effects and interaction-effects versions of our housing consumption models.

Because one possible response to a serious health shock is a move into a nursing homea move that removes someone from the household sector in which "rooms per person" is a meaningful measure of housing consumption—we must account for selective loss from our community-based sample of individuals. We do so by including in our model a separate equation for moves into nursing homes. A recent paper by Goda, Golberstein and Grabowski (2010) overlaps considerably with the institutional-selectivity component of our analysis. Goda et al. use the same data source as we do (although they use different survey years, and a different set of survey respondents) and also use a variation on the same Engelhardt-Gruber instrument for Social Security income as we do; their findings, however, are quite different from ours. We return to these issues in the final section of this paper.

\section{Data}

Sample. The data for our analysis come from the Health and Retirement Study (HRS). The analysis is confined to HRS respondents born during the period 1903-1928, because those are the years for which the Engelhardt-Gruber instrument can be applied. We use the 1995, 2000, 2002, 2004 and 2006 waves, and in each case condition on the respondent's situation two years prior to the interview. As in much of the literature on living arrangements among older persons, we limit our attention to unmarried individuals. Not only are living arrangements very different according to the presence or absence of a spouse, but the "marital shocks" that are central to our research question have little relevance for those who remain married. Moreover, due to sample size restrictions we limit our analysis to unmarried women. Much of the past 
literature on late-life housing consumption or household composition has also focused on the older female population.

As explained below, both our "health shock" and our "marital shock" variables measure changes in status over the two-year period preceding an HRS interview-i.e., since the previous interview. We are particularly interested in housing consumption adjustments to such shocks. One such adjustment, particularly in the case of a severe health shock, is a move from the community into a nursing home. In order to focus the analysis on these adjustments, our sample pools one to five instances of two-year "windows" on respondents' lives; for each such window (e.g., 1993 to 1995) we include individuals who were community residents at the beginning of the window, but may be either community or nursing home residents at the end of the window. Our final sample includes 3,608 individuals that contribute a total of 9,224 person-years of information to the estimation.

Dependent variables. Rooms per person (RPP) is based on the number of rooms in the household divided by the number of persons in the household. This variable measures housing consumption in terms of "volume” or "crowing” rather than in dollar terms (i.e., housing equity) or portfolio-composition terms (i.e., the share of wealth held in the form of housing). Adjustments to rooms per person can take the form of changes in the size of the housing unit occupied (the numerator of RPP), or in the number of occupants (the denominator of RPP), or both. These adjustments, in turn, may be the result of a residential move by oneself (which may or may not entail the sale or purchase of a house) or by others. Nursing-home residence was determined with information from the HRS's “tracker” file. For each biennial person-wave observation in our pooled analysis file (1993-1995, 1998-2000, 2000-2002, 2002-2004 or 20042006) we included only cases in which respondents were community resident at the start of the 
two-year period.

Figure 1 displays the components of the rooms-per-person outcome. The sample counts shown come from the pooled sample of unmarried women. The household size variable (the denominator of RPP) is very skewed; over $70 \%$ of cases consists of women living alone. The discrete "rooms" variable is, in contrast, close to symmetric. Figure 2 plots the rooms-perperson variable, with values grouped into half-unit bins. The RPP variable is not so symmetric as the "rooms" variable found in its numerator; however, tests of the normality of both the “rooms” and the RPP variables reject the null hypothesis.

Independent variables. A major component of retirement income is Social Security income (Clark et al. 2004). Our income measures use monthly household income components variables from the RAND-HRS files (http://hrsonline.isr.umich.edu/modules/meta/rand/index.html). For most of our analysis we restrict our income measure to Social Security retirement income (which excludes SSDI). “Total” income adds to this any earnings, pensions, unemployment benefits and income from capital, but excludes government transfers (which may be conditioned on household composition) as well as “other” income (which includes irregular sources such as lump-sum distributions). Past research suggests that increasing income in general, and increasing Social Security income in particular, leads to smaller households, greater homeownership, and a greater tendency to live alone at older ages. We also control for income in our nursing-home "selection" equation. Because a large proportion of nursing home stays are Medicaid-financed, and Medicaid is means-tested, we would expect to see that higher-income individuals are less likely to move into nursing homes. A recent meta-analysis of predictors of nursing home admissions concluded that low-income individuals were more likely to be admitted (Gaugler et al. 2007); 
Goda et al. (2010) also found a negative relationship between household Social Security income and nursing home use among HRS respondents over the 1993-1995 period.

Given the presumed endogeneity of income in a housing-consumption equation, we use as an instrument the variable originally described in Engelhardt and Gruber $(2004,2006)$. This series captures the part of variability in Social Security entitlements that is uniquely produced by exogenous policy changes. In deriving this data series, a standard (i.e. average) earnings history for someone born in 1916, adjusted for each of 4 levels of educational attainment, is first adjusted for inflation so as to pertain to birth years 1900 through 1928, and then used as the basis for calculating an annualized Social Security benefit for someone born in that year, reflecting the Social Security policy environment specific to those born that year. Further details about the derivation of the instrument can be found in Engelhardt and Gruber (2004, 2006); the instrument has also been used in other studies including Engelhardt (2008) and Engelhardt, Gruber and Perry (2005).

Figure 3 shows the time path of the instrument at each level of educational attainment over the 1900-1928 period. There is a roughly-linear pattern to these time trends, sharply broken for those in the "notch" cohorts, i.e., those born 1915-1917. The underlying trends are much steeper for those in the higher, compared to those in the lower, levels of educational attainment. Some studies have adopted a simpler version of this instrument, in particular a dichotomous variable coded 1 for those born in the "notch" years and zero otherwise (Moran \& Simon 2006; Goda, Golberstein \& Grabowski 2010). Judging by the patterns shown in Figure 3, the dichotomous-variable approach overlooks a great deal of between-cohort variability in the instrument, although the variability that is overlooked is highly correlated with year of birth (or, in cross section, current age). 
The instrument captures policy-induced variation in Social Security benefits associated with a worker's own-earnings history. Our analysis, however, is restricted to older unmarried women; because a substantial proportion of ever-married women receive a benefit based on a former husband's earnings, the appropriate value of the Social Security instrument is frequently the one that corresponds to the former husband's year of birth rather than the beneficiary's year of birth. Unfortunately, the HRS data tell us neither the nature of the benefit (i.e., worker benefit or surviving widow benefit) nor the former husband's year of birth. Accordingly, we follow past practice among users of this data series (Engelhardt, Gruber \& Perry 2005; Moran \& Simon 2005; Goda, Golberstein \& Grabowski 2010), matching the instrument to the year of birth, minus three, among ever-married women and to the woman's own year of birth among never-married women.

The other key variables used in our analysis measure Health shocks and Marital shocks. Health shocks include changes in the following health conditions that occurred between the observed wave and the previous wave: diabetes, cancer, lung disease, heart disease, stroke, and a broken hip. A single dichotomous variable captures those experiencing any of these 6 health transitions; however, in one sensitivity analysis we investigate the effects of selected individual health shocks. Marital shocks measure whether the respondent changed from being married to unmarried since the last wave.

Our analysis includes several additional covariates including age, race (1=black), education (less than high school, high school graduate (reference), and greater than high school), foreign born (1=yes), and the numbers of sons and daughters.

Identification of the rooms-per-person equation requires that at least one variable that appears in the nursing home (selection) equation be excluded from the housing consumption 
equation. State-specific Medicaid policy features arguably satisfy these requirements; Medicaid is a major payer of nursing home costs, and states differ substantially with respect to Medicaid eligibility and other programmatic features (Houser, Fox-Grage \& Gibson 2008; Kaiser Commission on Medicaid and the Uninsured 2010). These policy attributes, in turn, have been shown to influence both the supply of (Miller et al. 1999) and the demand for (Reschovsky 1998) nursing home beds. The public-use HRS data used in our analysis does not include codes for the state of residence. Therefore, we attempt to approximate the state-level policy variation in determinants of nursing home entry using a series of 9 region-of-residence indicator variables.

Summary statistics for the pooled analysis sample are shown in Table 1 . The sample is relatively old (mean age $=82$ ), and only about $20 \%$ have more than a high school education. The average amount of Social Security income $(\$ 10,230)$ is about half that of total income $(\$ 20,710)$, but the relative variability in total income greatly exceeds that of Social Security income. Nearly $20 \%$ have experienced a health shock in the preceding two years, while about 7\% have experienced a marital shock; the latter is, in almost all cases, an indicator of a spouse's death. About 7\% have entered (and remain in) a nursing home over the 2-year period preceding the interview; among those who remain in the community, housing consumption averages around 4 rooms per household occupant.

\section{Statistical Model}

The rooms-per-person outcome is meaningful only for community-resident individuals, yet health shocks, in particular, may lead to a period of residence in a nursing home-possibly for the rest of one's life. Therefore, it is important to recognize the potential for selection effects among those who remain in the community. And, as noted earlier, we also wish to use instrumental-variables techniques to rid our estimates of endogeneity bias. Therefore we adopt 
the following three-equation model for our analysis:

$$
\begin{gathered}
\text { Income }_{i t}=X_{i t} B_{1}+Z_{1 i} A_{11}+Z_{2 i} A_{12}+\theta_{1 i}+e_{1 i t} \\
\mathrm{NH}_{i t}^{*}=X_{i t} B_{2}+\delta_{2} \text { Income }_{i t}+Z_{2 i} A_{2}+\theta_{2 i}+e_{2 i t} \\
\mathrm{RPP}_{i t}=X_{i t} B_{3}+\delta_{3} \text { Income }_{i t}+\theta_{3 i}+e_{3 i t} .
\end{gathered}
$$

In (2), $\mathrm{NH}_{i t}^{*}$ is a latent indicator of nursing home occupancy, so $\mathrm{NH}_{i t}=1$ if $\mathrm{NH}_{i t}^{*}>0 . \mathrm{RPP}_{i t}$, which represents rooms per person, is observed only for those not in nursing homes, i.e., those for whom $\mathrm{NH}_{i t}=0 . X_{i t}, Z_{1 i}$, and $Z_{2 i}$ are exogenous variables. The $\theta_{j i}$ represent person-specific time-invariant unmeasured factors, which can be correlated across equations, while the $e_{j i}$ are classical errors. We assume that all the error components are normally distributed; the variance of $e_{2 i t}$ is normalized to one for identification.

Equation (1) is a reduced-form expression for current income. The vector $Z_{1}$ includes the instrument for Social Security income, as well as interactions of that instrument with exogenous variables (black and foreign born). Because the instrument is cohort-specific, it does not capture any within-cohort variability in permanent income other than the variability associated with educational attainment. The time-invariant person-level variable $\theta_{1 i}$ thus captures within-cohort variability, in the form of deviations from cohort-specific means. Equations (2) and (3) also contain time-invariant person-level unmeasured effects $\left(\theta_{2 i}\right.$ and $\left.\theta_{3 i}\right)$. Failure to account for these factors would produce biased estimates of the effect of income on each of the housing outcomes, due to their assumed correlation with $\theta_{1 i}$. The selection equation, (2), contains a set of instruments, $Z_{2}$, which are assumed to influence the propensity to enter a nursing home but not to influence the housing consumption of those who remain in the community, i.e. the region-ofresidence variables described above. We use aML software (Lillard and Panis 2003) to obtain full-information maximum-likelihood estimates of equations (1) - (3). 
We also present fixed-effect estimates of (3); given the assumed model structure, withinindividual differences in the rooms-per-person outcome are not influenced by $\theta_{3 i}$, and the correlation between unmeasured determinants of housing consumption and the decision to enter a nursing home is removed by differencing. Therefore, by assumption, the FE estimator suffers from neither endogeneity nor selection bias.

\section{Results}

Strength of instruments. Although we are not using 2SLS, we are nevertheless concerned that the instruments are reasonably strong predictors of income, either total income or Social Security benefits. However, in contrast to past research that uses the same (or a closely related) instrument, we find that the instruments perform rather poorly in our sample. In singleequation ML estimates of equation (1), a likelihood-ratio test of the restriction $a_{1, I}=a_{1, I^{*} \text { Black }}=$ $a_{1, I^{*} \text { ForBorn }}=0^{1}$ produces a $\chi^{2}$ statistic of $1.482(\mathrm{p}=0.686)$ when total income is used as the dependent variable, and a $\chi^{2}$ statistic of $5.218(\mathrm{p}=0.239)$ when Social Security income is used as the dependent variable. The instruments do a better job of predicting Social Security income than total income, but in neither case do they have much explanatory power. Because equation (1) includes a person-specific random effect, which like the instrument itself is time-invariant, it may be that some of the explanatory power that would otherwise be attributed to the instrument is absorbed by the random effect. To investigate this possibility, we re-estimated (1) without the random effect, with and without the instruments. The standard errors of the latter equations are plainly incorrect (inasmuch as they ignore the clustering of the sample at the individual level) but the maximized values of the likelihoods, upon which the LR test is based, are unaffected by the

\footnotetext{
${ }^{1}$ Here "I" represents the Engelhardt-Gruber instrument, while Black and ForBorn (indicating those born outside the U.S.) are assumed to be exogenous predictors of income.
} 
clustering. Here, we obtain a $\chi^{2}$ statistic of $7.628(p=0.054)$, a substantial improvement on the earlier tests.

There is no clear correspondence (of which we are aware) between the accepted threshold for a "strong” instrument—generally, an F-statistic of 10 in the first stage of 2SLS —and the LR test statistics produced in ML estimation. Nevertheless, the Engelhardt-Gruber instrument performs unexpectedly poorly in our analysis, especially in contrast to the results reported by Goda, Golberstein and Grabowski (2010): Goda et al. recode the instrument into a dichotomous variable, in the process eliminating the variability associated with level of education. Moreover, they apply it to a single wave of HRS data (corresponding to our 1993-1995 person-year observations), using it in a sample that combines married and unmarried men and women (in contrast to our sample of unmarried women). For those with less than a high school education, they report F-statistics ranging from 18 to more than 32 depending on how the equation is specified (i.e., incorporating linear, quadratic, or cubic age effects).

As a further test of the explanatory power of the instruments, we produced OLS estimates of equation (1) separately by interview year, using both total and Social Security income as the dependent variable. We also ran these equations with and without controls for current age, because in cross-section current age and the value of the Engelhardt-Gruber instrument are strongly associated. F-statistics for this set of estimates are reported in Table 2. It is evident that the instruments perform poorly in every case.

It is well known that limited-information ML performs better than 2SLS in the presence of weak instruments (Angrist \& Pischke 2009), a result that presumably carries over into our full-information ML setting as well. Nevertheless, we must be cautious in our interpretations of the estimated effects of income on both nursing home occupancy and housing consumption. 
Alternative measures of income. While income from any source can be used to pay for housing services, Social Security is much more widely received than are other income sources, so that it may have a distinctive "first dollar" effect on housing consumption. Moreover, the instruments are more closely tied—both theoretically and empirically— to Social Security than to total income. Table 3 presents estimated income effects for each income measure, for three different forms of the housing consumption model. The one-equation version considers equation (3) (for RPP) in isolation, ignoring both selection and endogeneity; the two-equation version includes the selection equation but ignores endogeneity. In all cases, the Social Security income measure produces point estimates larger in absolute value than the corresponding estimates that use total income. In the remainder of the paper, all results come from models that use the Social Security measure of income.

Main-effects models. Results for "main effects" versions of the model appear in Table 4; here, income and the health and marital shock variables enter linearly in the nursing home and housing consumption equations. The variations on random-effects models headed (1), (2), and (3) correspond to the one-, two- and three-equation versions summarized in Table 3. These variations on the model are presented in order to illustrate an important point: we obtain the usual result—i.e., that increases in income promote an increase in housing consumption—only if we disregard both selection into nursing homes and the endogeneity of income. The point estimate and SE for the effect of income on RPP in the 2-equation model are almost identical to their counterparts in the one-equation model, but the significance level increases slightly [in (2) the $p$-value for the effect of income on housing consumption is 0.052$]$. When we account for both selection and endogeneity, the effect of income on housing consumption becomes zero, and the effect of income on nursing home occupancy becomes—unexpectedly—positive and 
significant.

Selection into nursing homes is evident in other respects as well: those experiencing a health shock are much more likely to enter a nursing home over a 2-year interval. Covariate effects are also in the anticipated direction, with less educated people more likely, and those with more daughters less likely, to enter a nursing home. There is also a strong positive age gradient in the entry into nursing homes.

However, net of its unexpectedly positive effect on selecting people from the community into nursing homes, we find no evidence that income is associated with housing consumption, in the rooms-per-person equation. The health shock and martial shock variables, however, are significant: a health shock produces a decline in housing consumption, while a marital shock produces relatively large increase in housing consumption. We also find significant age, education, and family-size effects on housing consumption. The random effects in the nursing home and the housing-consumption equations are negatively correlated, suggesting further selectivity along unmeasured dimensions.

Finally, the last column of Table 4 presents the fixed-effects estimator of the RPP equation; as noted before, under the maintained assumptions this within-subject estimator, based on the community-dwelling subsample, are free of both endogeneity and selectivity biases. The point estimates in the FE equation are largely consistent with their counterparts in the threeequation version of the RE model; again, we find no effect of Social Security income on housing consumption.

Interaction models. Table 5 presents findings from a model in which income is interacted with both of the shock variables. If the mechanism through which income influences living arrangements in late life is that of buffering or moderating the consequences of health and 
marital events, then we should expect to see significant interactions between income and one or both of these shock variables. It could also be the case that despite our failure to find main effects of income on housing consumption, there could be interactive effects, in the presence of health or martial shocks. Instead, however, we find that the main effects of income and health shocks on nursing home occupancy remain; we also continue to find a marital-shock effect on housing consumption, but none of the other key variables are significant.

Disaggregated health shocks. As a final test of the sensitivity of our results to model specification, we partially disaggregated the health shock variable, isolating three of the more serious of the six type of health changes — stroke, hip fracture, and a new diagnosis of heart disease — while grouping the remaining three—diabetes, cancer and lung disease—into an "other" health shock category. Results obtained using the three-equation random effects and the fixed-effects versions of the model are summarized in Table 6. Both stroke and hip fractures have very large effects on nursing home occupancy, but net of this selection effect they also reduce housing consumption. However, in the FE estimates only the stroke effect is statistically significant. The "other" category continues to influence nursing home occupancy, although with a smaller magnitude than in the main-effects version of the model. The most serious health shocks, of course, are the fatal shocks that remove individuals from the sample altogether; we have not, however, attempted to introduce separate controls for selective mortality.

\section{Discussion}

While it is widely accepted that Social Security has contributed to trends away from shared households and towards smaller households, more home ownership and a greater tendency to live alone at older ages, the mechanism through which these trends operate has remained largely unexplored. We investigated the possibility that income in general, and Social 
Security income in particular, promote independent living in old age by buffering the consequences of major life events such as health shocks and marital shocks. The "buffering" hypothesis implies an interactive effect of income and such shocks on housing consumption.

However, not only did we not find any evidence of interactive effects of income and either health or marital shocks on housing consumption, we did not even find main effects of income on housing consumption, placing our results at odds with much published economic and demographic research. One possible explanation for this discrepancy is that much past work, especially in the demographic literature, has failed to address the endogeneity of Social Security income. Indeed, when we estimate a "naïve” version of our housing-consumption model [e.g., model (1) in Table 4], we do obtain the usual result: there is a positive effect of Social Security income on our measure of housing consumption, rooms per household member. Another limitation of much past research on late-life household composition is its failure to account for selective losses from the community-dwelling population into nursing homes. The HRS data, which tracks sample members who transition from the community into a nursing home, permits us to model this selection factor. When we do so (and whether or not we treat income as endogenous) we no longer find a positive effect of income on housing consumption.

We do, however, find main effects on housing consumption of the two "shock" variables considered. Health shocks, and especially relatively catastrophic shocks such as a stroke or a hip fracture (see Table 6), produce substantial reductions in housing consumption, conditional on remaining in the community. These reductions surely reflect the individual's increased need for hands-on help and assistance with daily tasks, a type of help that is facilitated by (and may even necessitate) coresidence with a helper. For many such health shocks, the period of dependency 
on others may be temporary, and a subsequent recovery of function may be accompanied by a further adjustment in housing consumption.

We find a positive, rather than a negative, effect of marital shocks on housing consumption. One might anticipate that a widow's response to her husband's death-the most common form that the "marital shock" takes in our sample-is to reduce housing consumption through downsizing or coresidence with another family member. However, past research has found fairly low rates of mobility among the older population, as well as a tendency for those who move to maintain their housing equity. Moreover, some qualitiative research (e.g., Shenk, Kuwahara \& Zablotsky 2004) points to the strong degree to which older widows’ personal identities are linked to their homes and possessions. Thus, it is unsurprising that in our sample, those experiencing a marital shock also experience a significant increase in housing consumption: for many individuals, the number of rooms in the house they occupy (the numerator of RPP) remains the same, while the number of household occupants (the denominator of RPP) decreases by one.

Part of the explanation the insignificance of income in our housing-consumption equation may lie in our use of an atypical measure of housing consumption, namely the rooms-per-person variable. Past research has generally focused on categorical measures of household composition (e.g., living alone versus with others; or, living in each of several possible family-group categories), or on dollar-denominated measures of housing consumption (e.g., housing wealth, which is surely positively correlated with dwelling unit size). Our RPP measure combines both dwelling unit size and household size, and therefore reflects adjustments along multiple dimensions including moves made by either the respondent or other family members, with or without changes in dwelling unit size such as those associated with downsizing. It is possible 
that income has sufficiently different effects on these components that any overall effect is obscured; we leave this possibility as a topic for later consideration.

Another potentially important feature of our analysis is its use of a two-year "window" over which the health-shock and marital-shock variables are measured. It would be possible to investigate current-period responses to more distant shocks, such as those that occurred between two and four years prior to interview, and so on. Doing so would entail imposing further conditions on sample selection, and would also reduce sample size; it may be, however, that housing consumption adjustments play out over a period of several years, and that there is an interactive effect of income on those longer-term reactions to health or marital shocks.

We also find that the Engelhardt-Gruber instrument for Social Security income performs poorly in our application, in striking contrast to its performance in several past studies. The contrast to the results reported by Goda, Golberstein and Grabowski (2010) is particularly surprising, in view of the overlap of samples and measures across the two studies. Some of the differences and similarities between the two studies have already been mentioned; other differences include the fact that they confine their analysis to the low-education sample, while we use individuals at all levels of educational attainment; they use couples as well as single individuals, while we use unmarried women only; they include decedents between 1993 and 1995, while we condition on survivorship (in all two-year periods); and, they use sample weights while we do not (and we cannot, inasmuch as the nursing home residents are given HRS sampling weights equal to zero). None of the enumerated differences across studies seem to us to provide a compelling explanation for the large differences in strength-of-instrument tests across the two studies. We are left with a speculation that the errors-in-variables problem with the instrument (i.e., the fact that the woman's Social Security benefit is based on the earnings 
history of a former husband whose unknown year of birth is something other than 3 years prior to hers) is exacerbated in our unmarried-women-only sample. 


\section{References}

Angel, J. (1991). Health and living arrangements of the elderly. New York: Garland Publishers.

Angel, J., G. De Jong, G. Cornwell, and J. Wilmoth. (1995). Diminished health, nonmetropolitan residence, and premature institutionalization: Evidence from the Longitudinal Study on Aging. National Journal of Sociology 9: 31-57.

Angrist, J.D. \& J.-S. Pischke (2009). Mostly Harmless Econometrics. Princeton University Press.

Avery, R., A. Speare, and L. Lawton (1989). "Social support, disability, and independent living of elderly persons in the United States.” Journal of Aging Studies 3: 279-293.

Bradsher, J.E., C. F. Longino, Jr. D. J. Jackson, and R. S. Zimmerman. (1992). Health and geographic-mobility among the recently widowed. Journals of Gerontology, 47(5), S261S268.

Clark, R.L. R. V. Burkhauser, M. Moon, J. F. Quinn, and T. M. Smeeding. 2004. The economics of an aging society. Malden, MA: Blackwell Pub.

Costa, D.L. (1999). "A House of Her Own: Old Age Assistance and the Living Arrangements of Older Nonmarried Women.” Journal of Public Economics 72:39-59.

Duncombe, W., M. Robbins, M. and D. A. Wolf, (2003). Place characteristics and residential location choice among the retirement-age population. Journal of Gerontology: Social Sciences, 58(4): S244-S252.

Engelhardt, G.V. (2008). “Social Security and Elderly Homeownership.” Journal of Urban Economics 63:280-305.

Engelhardt, G.V. and J. Gruber (2004). "Social Security and the Evolution of Elderly Poverty.” NBER Working Paper 10466 (May).

Engelhardt, G.V., J. Gruber and C.D. Perry (2005). "Social Security and elderly living arrangements.” Journal of Human Resources 40:354-372.

Engelhardt, G.V. and J. Gruber (2006). "Social Security and the Evolution of Elderly Poverty," Pp. 259-287 in A. Auerbach, D. Card and J. Quigley (eds.), Public Policy and the Distribution of Income. New York: Russell Sage Press.

Gaugler, J. E., Kane, R. L., Kane, R. A., Clay, T., \& Newcomer, R. (2003). Caregiving and institutionalization of cognitively impaired older people: Utilizing dynamic predictors of change. The Gerontologist, 43(2): 219-229. 
Gaugler, J. E., S. Duval, K. A. Anderson, \& R. L. Kane (2007). "Predicting nursing home admission in the U.S: a meta-analysis.” BMC Geriatrics 7:13 (http://www.biomedcentral.com/1471-2318/7/13).

Goda, G.S., Z. Golberstein \& D.C. Grabowski (2010). "Income and the utilization of long-term care services: Evidence from the Social Security benefit notch.” NBER Working Paper no. 16076 (http://www.nber.org/papers/w16076).

Haas, W. H. and W. J. Serow. (1993). Amenity retirement migration process: A model and preliminary evidence. The Gerontologist, 33(2), 212-220.

Holden, K.C. (1988). "Poverty and Living Arrangements Among Older Women: Are Changes in Economic Well-being Underestimated?” Journal of Gerontology: Social Sciences 43:S2227.

Houser, A., W. Fox-Grage \& M.J. Gibson (2008). Across the States: Profiles of Long-Term Care and Independent Living. AARP Public Policy Institute (online at http://assets.aarp.org/rgcenter/il/d19105_2008_ats.pdf; accessed July 2, 2010).

Kaiser Commission on Medicaid and the Uninsured (2010). Key Facts: Medicaid financial eligibility: Primary pathways for the elderly and people with disabilities. Online at http://www.kff.org/medicaid/8048.cfm (accessed July 1, 2010).

Lillard, L.A. and C.W.A. Panis (2003). aML Multilevel Multiprocess Statistical Software, Version 2.0. EconWare, Los Angeles, CA.

Litwak, E., and C. F. Longino, Jr. (1987). Migration patterns among the elderly: A developmental perspective. The Gerontologist, 27: 266-272.

Longino, C. F., D.E. Bradley, E. P. Stoller, and W. H. Haas. (2008). Predictors of non-local moves among older adults: A prospective study. Journal of Gerontology: Social Sciences, 63(1): S7-S14.

Longino, C. F., D. J. Jackson, R.S. Zimmerman, and J. E. Bradsher. (1991). The second move: Health and geographic mobility. Journal of Gerontology: Psychological Sciences and Social Sciences, 46: 218-224.

McAuley, W. J., and P. M. Usita. (1998). A conceptual model for the mobility patterns of Nursing Home admissions. The Gerontologist, 38(6): 726-734.

McGarry, K. and R.F. Schoeni (2000). "Social Security, Economic Growth, and the rise in elderly widows' independence in the Twentieth Century.” Demography 37:221-236.

Macunovich, D.J., R.A. Easterlin, C.M. Schaeffer \& E.M. Crimmins (1995). "Echoes of the baby boom and bust: Recent and prospective changes in living alone among elderly widows in the United States.” Demography 32: 17-28. 
Michael, R.T., V.R. Fuchs and S.R. Scott (1980). "Changes in the propensity to live alone: 19501976.” Demography 17:39-56.

Miller, M. E., C. F. Longino, Jr., R. T. Anderson, M.K. James, and A.S. Woley. (1999). Functional status, assistance, and the risk of a community-based move. The Gerontologist, 39: 187-200.

Miller, N.A., S. Ramsland, E. Goldstein \& C. Harrington (2001). "Use of Medicaid 1915(c) home- and community-based care waivers to reconfigure state long-term care systems.” Medical Care Research and Review 58: 100-119.

Moran, J.R. \& K.I. Simon (2006). "Income and the use of prescription drugs by the elderly: Evidence from the notch cohorts.” Journal of Human Resources 41: 411-432.

Mutchler, J. and J. Burr. 1991. "A longitudinal analysis of household and nonhousehold living arrangements in later life.” Demography 28: 375-390.

Palloni, A. (2001). "Living arrangements of older persons." Population Bulletin of the United Nations, Special Issue Nos. 42/43: Living Arrangements of Older Persons: Critical Issues and Policy Responses, pp. 54-110.

Reschovsky, J.D. (1998). "The roles of Medicaid and economic factors in the demand for nursing home care.” Health Services Research 33: 787-813.

Shenk, D., K. Kuwahara \& D. Zablotsky (2004). "Older women’s attachments to their home and possessions.” Journal of Aging Studies 18: 157-169.

Soldo, B., D. Wolf, and E. Agree. 1990. "Family, households, and care arrangements of frail older women: A structural analysis." Journal of Gerontology: Social Sciences 45:S238-249.

Stoller, E. P., \& Longino, C F. (2001). "Going Home” or "Leaving Home”? The impact of person and place ties on anticipated counterstream migration. The Gerontologist 41: 96102.

Tissue, T. and J.L. McCoy (1981). "Income and Living Arrangements Among Poor Aged Singles.” Social Security Bulletin 44:3-13.

Venti, S.F. and D.A. Wise (1989). “Aging, Moving, and Housing Wealth.” Pp. 9-48 in D.A. Wise (ed), The Economics of Aging. Chicago: The University of Chicago Press.

Venti, S.F. \& D.A. Wise (1990). "But they don’t want to reduce housing equity.” Pp. 13-29 in D.A. Wise (ed.), Issues in the Economics of Aging. Chicago: The University of Chicago Press.

Wolinsky, F.D., C. M. Callahan, J.F. Fitzgerald, and R. J. Johnson. (1993). Changes in functional status and the risks of subsequent nursing home placement and death. Journal of Gerontology: Social Sciences, 48: S93-S101. 


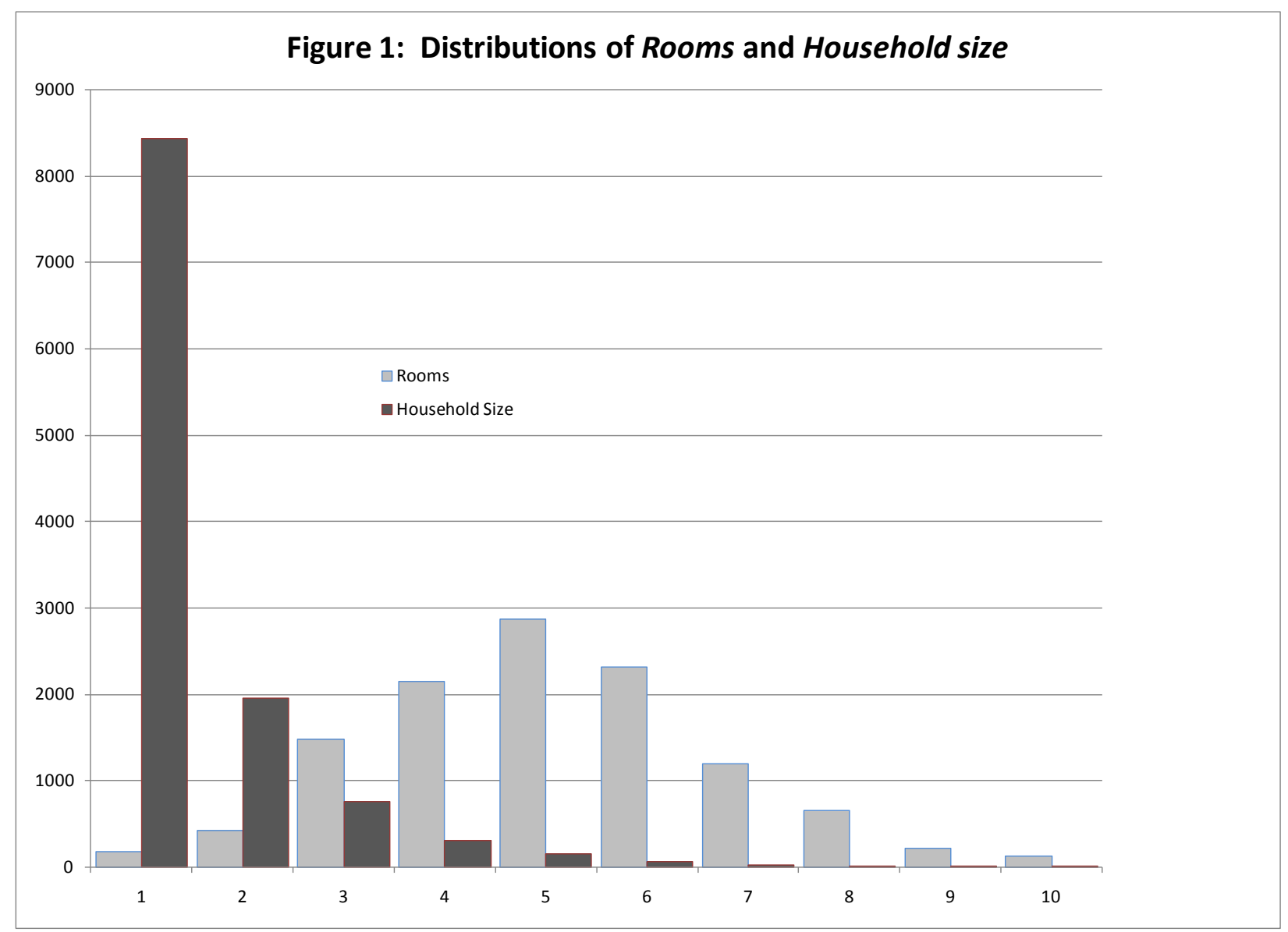




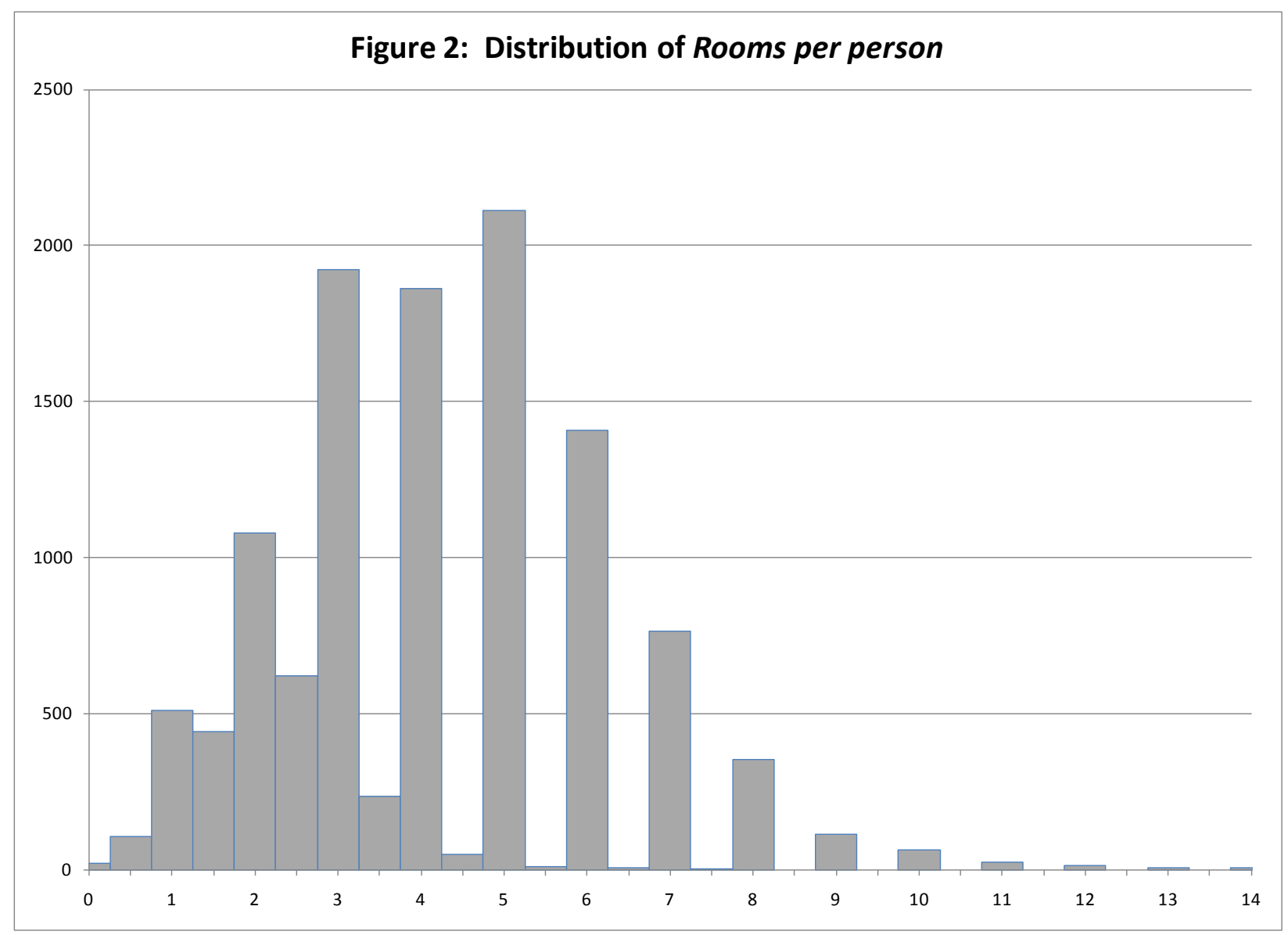




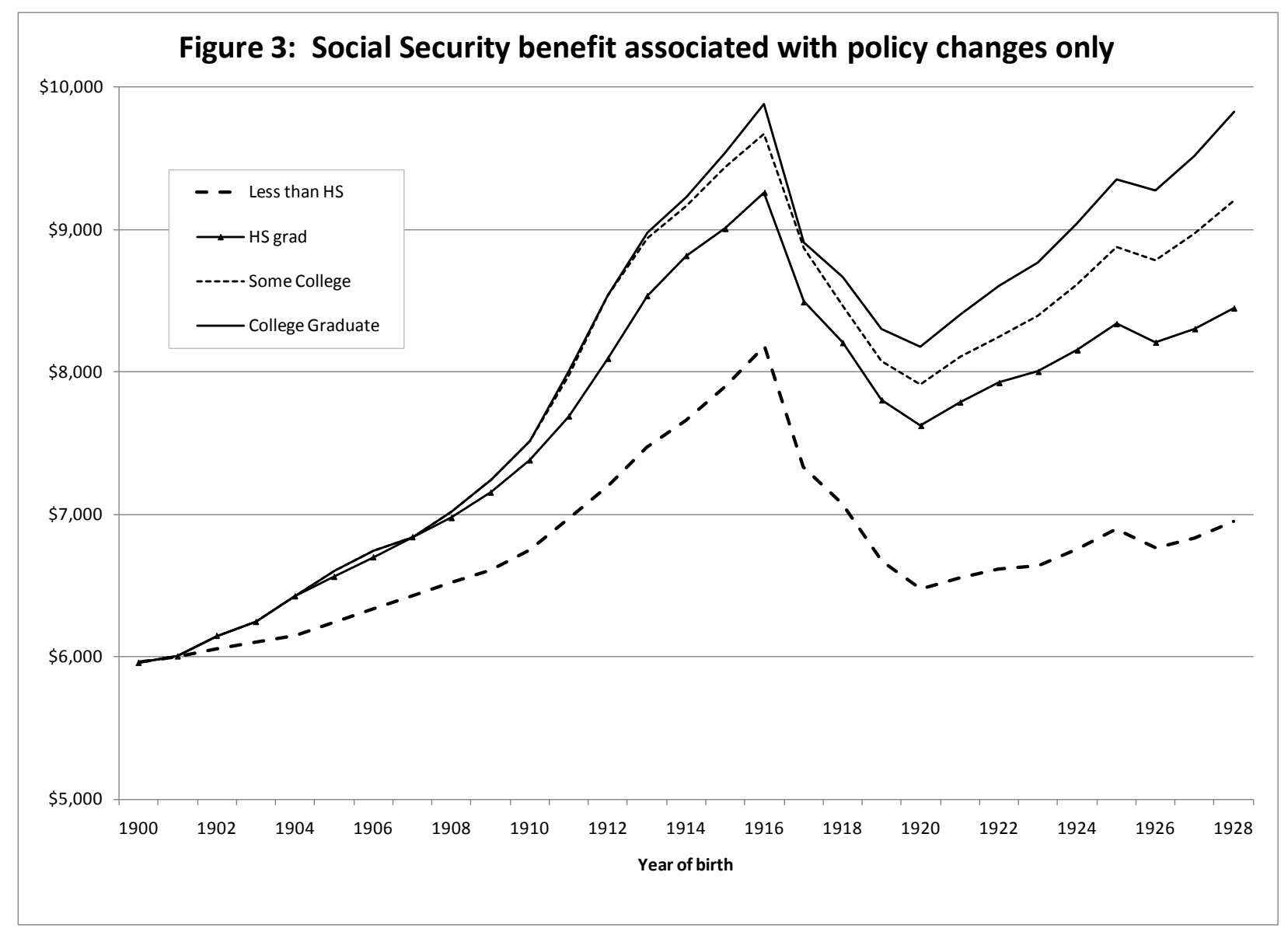


Table 1: Summary statistics for pooled analysis sample

\begin{tabular}{lrr}
\hline \hline & Mean (\%) & \multicolumn{1}{c}{ SD } \\
\hline Total income (1000s) & 20.71 & 38.78 \\
Social Security income (1000s) & 10.23 & 5.08 \\
Instrument (1000s) & 7.69 & 0.92 \\
Health shock & 18.56 & \\
$\quad$ Stroke & 4.18 & \\
$\quad$ Broken hip & 3.33 & \\
$\quad$ Heart disease & 6.88 & \\
Marital shock & 6.57 & \\
Age & 82.26 & 5.69 \\
Black & 15.56 & \\
Foreign born & 8.88 & \\
Less than high school & 39.35 & \\
Greater than high school & 19.83 & \\
Sons & 1.33 & 1.38 \\
Daughters & 1.40 & 1.39 \\
NH & 7.14 & \\
RPP & 4.17 & 1.92 \\
$n$ & 9224 & \\
\hline
\end{tabular}

${ }^{\mathrm{a}}$ Dichotomous variable; reported mean is percentage of cases in the 1 category. 
Table 2: F statistics for single-wave tests of instrument set

\begin{tabular}{lccccc}
\hline \hline & & & & & \\
Survey year: & 1995 & 2000 & 2002 & 2004 & 2006 \\
\hline $\begin{array}{l}\text { Dependent variable } \\
\quad \text { Total income }\end{array}$ & & & & & \\
$\quad$ Age variables included & 0.27 & 0.29 & 0.57 & 1.32 & 0.20 \\
$\quad$ Age variables excluded & 0.28 & 1.36 & 1.10 & 1.33 & 0.17 \\
& & & & & \\
$\quad$ Social Security income & & & & & \\
$\quad$ Age variables included & 2.36 & 3.09 & 0.62 & 0.13 & 0.54 \\
$\quad$ Age variables excluded & 1.43 & 3.24 & 0.96 & 0.04 & 0.57 \\
$\quad$ & & & & & \\
Sample size: & 2473 & 2419 & 1983 & 1689 & 1360 \\
\hline
\end{tabular}

Numerator d.f. $=3$ in all cases; OLS estimates. 
Table 3: Estimated effects of alternative measures of income

\begin{tabular}{|c|c|c|}
\hline \multirow[t]{2}{*}{ Measure } & \multicolumn{2}{|c|}{ Dependent Variable } \\
\hline & $\mathrm{NH}$ & $\mathrm{RPP}$ \\
\hline \multicolumn{3}{|l|}{ Total income } \\
\hline One-equation model & -- & $\begin{array}{c}0.0015 \text { ** } \\
(0.0015)\end{array}$ \\
\hline Two-equation model & $\begin{array}{r}-0.0028 \\
(0.0016)\end{array}$ & $\begin{array}{l}0.0015 \text { ** } \\
(0.0005)\end{array}$ \\
\hline Three-equation model & $\begin{array}{r}0.0022 \\
(0.0025)\end{array}$ & $\begin{array}{r}0.0004 \\
(0.0008)\end{array}$ \\
\hline \multicolumn{3}{|l|}{ Social Security income } \\
\hline One-equation model & -- & $\begin{array}{c}0.0066 \text { * } \\
(0.0033)\end{array}$ \\
\hline Two-equation model & $\begin{array}{c}-0.0037 \\
(0.0056)\end{array}$ & $\begin{array}{r}0.0063 \\
(0.0033)\end{array}$ \\
\hline Three-equation model & $\begin{array}{r}0.0180 * \\
(0.0186) \\
\end{array}$ & $\begin{array}{r}-0.0061 \\
(0.0037) \\
\end{array}$ \\
\hline
\end{tabular}

Standard errors in parentheses; * $p<0.05 ;{ }^{* *} p<0.01$. 
Table 4: Main-effects models

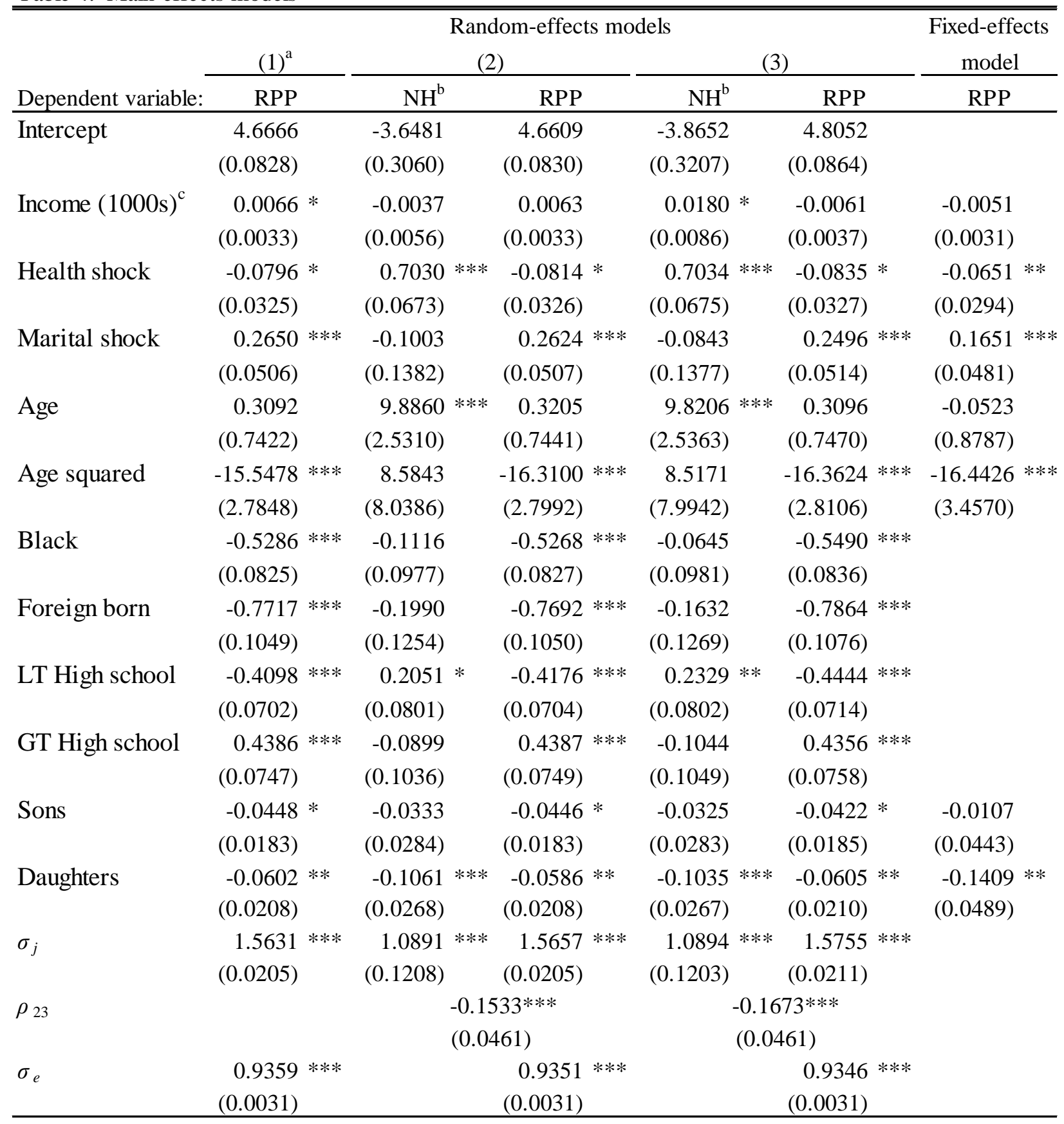

Standard errors in parentheses; $*<<0.05$; ${ }^{* *} p<0.01$; ** $p<0.001$.

${ }^{a}$ Models (1), (2) and (3) are the one-, two-, and three-equation versions summarized in Table 3.

${ }^{\mathrm{b}}$ The NH equation also contains 8 region-of-residence dummies.

${ }^{\mathrm{c}}$ Uses Social Security income only. 
Table 5: Interaction-effects models

\begin{tabular}{lccc}
\hline \hline & \multicolumn{2}{c}{ Random-effects model } & Fixed-effects model \\
Dependent variable: & $\mathrm{NH}$ & $\mathrm{RPP}$ & $\mathrm{RPP}$ \\
\hline & & & \\
Income $(1000 \mathrm{~s})^{\mathrm{a}}$ & $0.0185 *$ & -0.0044 & -0.0039 \\
& $(0.0091)$ & $(0.0038)$ & $(0.0033)$ \\
Health shock & $0.7003 * * *$ & -0.0024 & 0.0024 \\
& $(0.1381)$ & $(0.0724)$ & $(0.0655)$ \\
Marital shock & 0.1128 & $0.3154 *$ & 0.2009 \\
& $(0.3345)$ & $(0.1391)$ & $(0.1264)$ \\
Income x Health shock & 0.0004 & -0.0078 & -0.0064 \\
& $(0.0120)$ & $(0.0060)$ & $(0.0056)$ \\
Income x Marital shock & -0.0187 & -0.0060 & -0.0032 \\
& $(0.0283)$ & $(0.0114)$ & $(0.0103)$ \\
\hline
\end{tabular}

Standard errors in parentheses; ${ }^{*} p<0.05 ; * * * p<0.001$.

All models also control for age, age squared, black, foreign born, education, number of sons, and number of daughters.

${ }^{\mathrm{a}}$ Uses Social Security income only. 
Table 6: Disaggregated health-shock models

\begin{tabular}{lclc}
\hline & \multicolumn{2}{c}{ Random-effects model } & Fixed-effects model \\
Dependent variable: & NH & RPP & RPP \\
\hline & & & \\
Income (1000s) ${ }^{\mathrm{a}}$ & $0.0189 *$ & -0.0062 & -0.0052 \\
& $(0.0087)$ & $(0.0037)$ & $(0.0031)$ \\
Stroke & $1.1134 * * *$ & $-0.2380 * * *$ & -0.2142 \\
& $(0.1096)$ & $(0.0638)$ & $(0.0635)$ \\
Broken hip & $1.1208 * * *$ & $-0.1798 *$ & -0.1327 \\
& $(0.1175)$ & $(0.0739)$ & $(0.0800)$ \\
Heart disease & 0.1875 & -0.0165 & -0.0003 \\
& $(0.1033)$ & $(0.0527)$ & $(0.0441)$ \\
Other health shock & $0.2248 *$ & -0.0261 & -0.0308 \\
& $(0.1068)$ & $(0.0464)$ & $(0.0453)$ \\
Marital shock & -0.0662 & $0.2478 * * *$ & $0.1643 * * *$ \\
& $(0.1358)$ & $(0.0518)$ & $(0.0481)$ \\
\hline
\end{tabular}

Standard errors in parentheses; ${ }^{*} p<0.05$; ${ }^{* * *} p<0.001$.

All models also control for age, age squared, black, foreign born, education, number of sons, and number of daughters.

${ }^{a}$ Uses Social Security income only. 


\section{RECENT WORKING PAPERS FROM THE \\ CENTER FOR RETIREMENT RESEARCH AT BOSTON COLLEGE}

Adjusting Social Security for Increasing Life Expectancy: Effects on Progressivity

Courtney Monk, John A. Turner, and Natalia A. Zhivan, August 2010

Work and Retirement Patterns for the G.I. Generation, Silent Generation, and Early Boomers: Thirty Years of Change

Richard W. Johnson, Barbara A. Butrica, and Corina Mommaerts, July 2010

Spousal Health Shocks and The Timing Of The Retirement Decision in the Face of ForwardLooking Financial Incentives

Courtney Harold Van Houtven and Norma B. Coe, June 2010

Incorporating Employee Heterogenity Into Default Rules for Retirement Plan Selection Gopi Shah Godi and Colleen Flaherty Manchester, May 2010

Accurately Measuring Health Over the Life Course

Fabian Lange and Doug McKee, May 2010

Getting to the Top of Mind: How Reminders Increase Saving

Dean Karlan, Margaret McConnell, Sendhil Mullainathan, and Jonathan Zinman, April 2010

The Shrinking Tax Preference for Pension Savings: An Analysis of Income Tax Changes, 1985-2007

Gary Burtless and Eric Toder, March 2010

Social Security, Benefit Claiming and Labor Force Participation: A Quantitative General Equilibrium Approach

Selahattin İmrohoroğlu and Sagiri Kitao, March 2010

How Much Is Enough? The Distribution of Lifetime Health Care Costs

Anthony Webb and Natalia Zhivan, February 2010

Impact of Immigration on the Distribution of American Well-Being

Gary Burtless, December 2009

Actual and Anticipated Inheritance Receipts

Norma B. Coe and Anthony Webb, December 2009

Will Automatic Enrollment Reduce Employer Contributions to 401(k) Plans

Mauricio Soto and Barbara A. Butrica, December 2009

All working papers are available on the Center for Retirement Research website

(http://crr.bc.edu) and can be requested by e-mail (crr@bc.edu) or phone (617-552-1762). 